\title{
A slice of higher education - the widening gyre
}

BOOK TITLE:

As by fire: The end of the South African university

\section{BOOK COVER:}

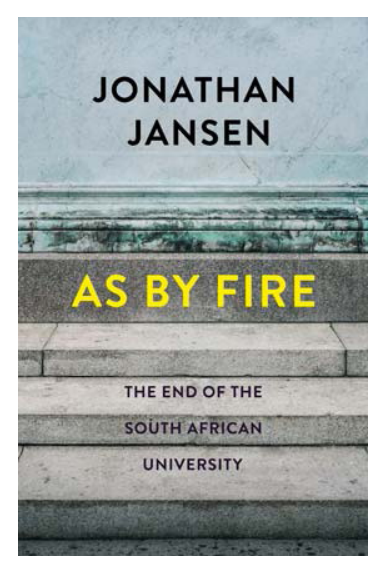

AUTHOR:

Jonathan Jansen

ISBN:

9780624080305 (softcover)

PUBLISHER:

Tafelberg, Cape Town; ZAR280

\section{PUBLISHED:}

2017

\section{REVIEWER:}

Robert J. Balfour

\section{AFFILIATION:}

Faculty of Education, North-West University, Potchefstroom, South Africa

\section{EMAIL:}

robert.balfour@nwu.ac.za

\section{HOW TO CITE:}

Balfour RJ. A slice of higher education - the widening gyre. S Afr J Sci. 2018;114(3/4), Art. \#a0260, 1 page. http://dx.doi. org/10.17159/sajs.2018/a0260

\section{PUBLISHED:}

27 Mar. 2018

(C) 2018. The Author(s). Published under a Creative Commons Attribution Licence.
Reading any one of Jonathan Jansen's books is like taking a slice of South Africa at a given moment in time. At the tip of the slice is a point. Knowledge in the Blood (UCT Press; 2009), took as its 'point' the experience of students in a period of profound change: captured still by the imaginary of a racialised past; that book described the experience of racism in a post-apartheid, but by no means post-racist, state. In attempting to understand what racist beliefs offered a generation of students (white and black), Jansen illustrated how identity politics and prospects could be shifted pending the intervention of a leader. So too in As by Fire, the 'point' of leadership in the \#FeesMustFall movement becomes the focus of intense reflections, often beginning as personal, and then widening to a social focus on the fissures of an increasingly divided South Africa in which the fractures tearing universities apart are revealed to be symptomatic of the post-apartheid state's approach to welfarism, the massification of education at the cost of limited and even declining expenditure on education in general, and higher education in particular.

The book demonstrates a researcher's skilful treatment of data, reportage, history and analysis and how the narratives of vice chancellors during the Fallist events understood their histories, the histories of their students and the context in which both came to forceful, and often times painful, confrontations between people tasked to lead and manage a crisis not of their making, against the students to whom their very professions, and sometimes even lives, are dedicated. The text casts vice chancellors in the same dialogic as that represented by a far more critical and self-serving press, as noted by Jansen himself. If the dialogic remains the same, the representations of leaders in this text seems to be a wilful correction to what Jansen obviously perceives as the vilification of vice chancellors as hapless subjects. By the time the book nears its conclusion, the reader comes to feel as though South Africa, as presented through the very different institutional contexts of 11 South African universities and their leaders, comes to be known, albeit from a very specific angle. The angle is not simply the individual in the text, but also the way in which the text is treated and the individual account is 'couched'. South Africa sceptics will almost inevitably attribute the Fallist crisis to a cocktail of failed African Nationalist Congress policies aided by a combination of greed and incompetence. But vignettes described by vice chancellors, all of whom are shown to be deeply committed to the broader transformation of education in South Africa, suggest a failure of another kind - a fundamental series of misrecognitions: of the potential of higher education to address wider social issues concerning centuries old inequalities, of the role of the university as a response to the welfare needs of the poor youth particularly, and of the capacity of the universities to adequately support let alone redress the inequities of a poor quality education system in South Africa. It is this last aspect that remains somewhat underexplored against the lack of adequate planning to enable the radical transformation of higher education commenced by Kader Asmal in 2004, to come to its full realisation in terms of the lived experience of transformation as a narrative of success, rather than a series of brutally experienced frustrations and disappointments (p.178).

The reality is evident all around us; government, through negligence, has helped create a two-tier education system: that which can be afforded by the enabled and that which cannot. Jansen's analysis of the missing middle affirms that the new apartheid cuts across race and gender lines of past exclusions, neither effacing nor erasing what has come before, but rather adding to inequality at the inter-sectionalities of race, class and gender. Although Jansen analyses the causes of the many stresses within the higher education sector, and although the book takes as its context the university as the setting for various spectacular confrontations, the role of the institution in South Africa (as opposed to in the UK, for example) receives too little attention in the book - a point to which I return later.

In As by Fire, the brunt of this public disappointment with the promise of education is carried by students and universities, and vice chancellors whose responses and reactions reveal the extent of the lack of foresight and sheer indifference by the state. In As by Fire, that moment or historical event begins with the rupture of the \#RhodesMustFall movement and charts the widening gyre (a deliberate reflection on Yeat's 'The Second Coming' and Achebe's echo of Things Fall Apart) associated with \#FeesMustFall and other Fallist movements across South Africa from 2015 to 2016. With the exception of Chapter 7, the chapters of this book rely on the testimony of university vice chancellors, as coordinated through the narrative of another vice chancellor - Jansen himself. The book aims at accessibility in terms of its anticipated audience and eschews any claim at rigorous research. However, underlying the narratives and the encompassing text, those who are aware of Jansen's research skills (and the many accounts he has written on higher education on far-reaching themes) will know that the insights provided arise from an acute and nuanced understanding of how an historical event comes to be generated; for example, in Chapter 8, the ambiguous connections between welfare and education as a perceived form of social welfare are described incisively.

These evident strengths noted, this book is one that offers sympathetic portraits of vice chancellors, not all of whom have been found - since its publication - to be as worthy of the praises sung by Jansen. The conclusions drawn are not unexpected: address the funding crisis and the schooling quality crisis; limit state interference; support the development of the black and female professoriate from within (and not through external mechanisms such as the NIHSS); and protect universities against the ravages of instability and insecurity. South Africa has known violent protest within institutions since the 1960s; thus it is not surprising that the book concludes with a sobering concern about the institutionalisation of violence. The antidote Jansen suggests is a renewal of a social contract - what is termed a solidarity between society and universities in opposition to elements or impulses towards the destruction of vulnerable institutions. 